\title{
THE NARCOTICS BUREAU AND THE HARRISON ACT: JAILING THE HEALERS AND THE SICK
}

\author{
RUFUS G. KING†
}

[This issue of the JOURNAL contains two studies of the narcotics problem. A Comment, beginning on page 751, presents a general survey of narcotics regulation. Mr. King's Article focuses on the interpretation and enforcement of the Harrison Act, and the resulting impact upon addicts and physicians.]

At last there are faint stirrings to suggest that this nation's policies towards its narcotic drug traffic may soon be exposed to a full critical re-examination and review. ${ }^{1}$ Nearly forty years have gone by since Congress passed the Harrison Act, ${ }^{2}$ intended partly to carry out a treaty obligation, ${ }^{3}$ but mainly to aid the states in combatting a local police problem which had gotten somewhat out of hand. ${ }^{4}$ In other areas of law enforcement, when Congress has thrown federal power into the balance, these local problems have usually diminished or disappeared. ${ }^{5}$ In the case of narcotics control, however, the indications are all quite to the contrary.

It must be conceded that there are large gaps in what we know about narcotics addiction and the illicit traffic. The Comment elsewhere in the JounN ${ }^{\circ}{ }^{\circ}$ presents a dispassionate collection of information and authorities. Yet there is simply not much to go by. When the federal authorities took over, we entered a forty-year eclipse; for years on end there has been nothing but the "official line" for those who wished to inquire into the stubject. But enough information is available to convince this writer, along with a handful of other

i Special Counsel, Subcommittee of House Committee on the Judiciary to Investigate the Department of Justice; Special Counsel, Investigations Subcommittee of Senate Interstate Commerce Committee.

1. See note 70 infra. See also SEN. Rep. No. 725, 82d Cong., 1st Sess. (1951); Hcarinlys before Special Committee to Investigate Organized Crime in Interstate Commcrec, 82d Cong., 1st Sess. pt. 14 (1951); Goldstern, Narcotics, A Report dy tue AtTorney GeNeral to the Legislature of the State of New York (Legis. Doc. No. 27, 1952).

2. 38 Stat. 785 (1914), 26 U.S.C. \& 2550 (1946).

3. The United States adhered to the Hague Opium Convention on January 23, 1912 (38 STAT. 1912 (1912)); this obliged adherents to control the manufacture, sale, use, and transfer of "morphine, cocaine and their respective salts."

4. See, H.R. Rep. No. 23, 63d Cong., 1st Sess. 2 (1913).

5. See, e.g., 31 Stat. 188 (1900), 18 U.S.C. $\$ 43$ (1946) (poaching); 41 STAT. 324 (1919), 18 U.S.C. \$§ 2312-13 (1946) (transportation of stolen vehicles); 47 STAT. 320 (1932), 18 U.S.C. \& 1201 (1946) (kidnapping).

6. Comment, Narcotics Regulation, 62 Yale L.J. 751 (1953). 
protestants, ${ }^{7}$ that the United States-alone among civilized nations-has driven relentlessly down the wrong road ever since the end of World War I. This article (which is not dispassionate) will relate the episode in our legal history which propelled our enforcement agencies along this road. But first it may be helpful to set forth a brief history of the relationship between the addict and his Government.

Our grievous error was in allowing the narcotics addict to he pushed out of society and relegated to the criminal community. He isn't a criminal. He never has been. And nobody looked on him as such until the furious blitzkrieg launched around 1918 in connection with the enforcement of the Harrison Act.

That Act was a tax measure. designed and intended to bring the damestic traffic in narcotics into the open under a licensing system, so that the sloppy dispensing practices of the day could be checked. It said nothing about "addicts" (partly because the word had not achieved its wide current usage). and specifically exempted the "patient" in bona fide doctor-patient relationships." Narcotics-users were "sufferers" or "patients" in those days; they could and did get relief from any reputable medical practitioner, and there is not the slightest suggestion that Congress intended to change this-leyond cutting off the disreputable "pushers" who were thriving outside the medical profession and along its peripheries.

Two things, very likely related, distorted this intent. The . Act was assigned. for enforcement, to the same righteous zealots who were undertaling another national mistake-enforcement of our then new Prohibition laws: $:^{\circ}$ and. secondly, a great public hullabaloo about the "dope menace" swept the country. ${ }^{10}$ The narcotics-user suddenly became a "dope fiend." Official esti-

7. See, c.g., Remarks of Hon. John M. Coffee, $\$ 3$ Covo. RE 2107 19331: Stevem, lake Dope Legal, Harpers Magazine, Nowember, 1952, p. 40; Statentent of Key. Cls seland M. Bailey, member of House Interstate and Foreign Commerce Committee, March 23, 1953.

8 . The exempting language, relieving from the duty to use Treasury-prescritisd order forms, 38 STAT. 786 (1914), 26 U.S.C. $\$ 2554$ (c) (1) (1946), is:

"Nothing contained in the section ... shall apply ... [t]o the dispensing or distribution of any of the drugs mentioned ... to a palicnt by a phiysicios, dentist, or zeterinary surgeon registered under section 3221 in the course of his professional practice only. ..." (Emphasis supplied.)

Those who avail themselves of this exemption must keep records of each transaction for a prescribed period.

9. Schmeckebier, The Burcan of Prohibition in Senrice M10:0onapH 57, I:Tsr. 103 Gov't Research, Brookmas INst. 3 (1929). The Narcoties Division vas merged intu the Prohibition Unit of the Treasury Department in 1920, and carricd into the Prohibition Bureau when the latter was created in 1927. Since 1930 it has bsen a scparate entity entitled the Federal Narcotics Bureau.

10. See, New York Times, April 10, 1919, p. 1; U.S. TREas. Der't, NeErutir of Speclal Coasunttee to Investigate the Trafhic in Nascutic Drugs (April 15, 1919) 
mates of the addict-population leapt to the fantastic figure of one millionmostly young folk, many "under the age of $20 . " 11$ The good people of our land were terrified. The Narcotics Division of the Treasury Department came charging to the rescue: our prisons began to fill, not with illicit peddlers only, but with addicts-and reputable medical men who had tried to help them. ${ }^{12}$ And there has been no surcease from that day to this.

In sum, the Narcotics Division succeeded in creating a very large criminal class for itself to police (i.e., the whole doctor-patient-addict-peddler community), instead of the very small one that Congress had intended (the smutggler and the peddler). Subsequent Division officials have sustained the enforcement-oriented propaganda barrage: the addict is a criminal, a criminal type, or laden with criminal tendencies; ${ }^{13}$ addicts can only be dealt with by being tracked down and isolated from society in total confinement; ${ }^{14}$ the cureall is more arrests and stiffer criminal penalties for all narcotics offenders ; ${ }^{15}$

(quoted in U.S. Treas. Dep't, The Traffic in Habit-Forming Nakcotic Dkugs (1923)).

11. U.S. Treas. Dep't, The Traffic in Habit-Forming Narcotic Drugs (1923). It is noteworthy that as soon as the Narcotics Division turned to reporting its enforcement achievements, this estimate dropped to 100,000 and remained at that figure until World War II.

12. As of June 30,1928 , of the 7738 prisoners in federal penitentiaries, 2529 were sentenced for narcotics offenses, 1156 for prohibition law violations, and 1148 for stolenvehicles transactions. Data are not available for approximately the same number in state institutions at this time. Schmeckebier, sipra note 9, at 143.

13. See, e.g., Federal Narcotics Bureau, Menorandum Regaruing Narcotic Clinics, Their History and Hazards 6 (1938):

"With regard to the plan which is in effect in Formosa, we have a valuable and informing contribution to our knowledge on the subject by Dr. Somei To of the Health Commission of Formosa. After classifying 57,073 crimes committed during seven years by natives of Formosa, his records show that based upon the relative proportion of opium users to non-users we find $70.83 \%$ crintinality among opium users as against $29.17 \%$ criminality among non-users. In Formosa, opium smoking is licensed and the cost of opitum is very small. UNDER THESE CONDITIONS THE ONLY ATTRIBUTABLE CAUSE FOR GREATER CRIMINALITY AMONG NARCOTIC ADDICTS THAN NON-ADDICTS IS THE DIRECT EFFECT OF THE USE OF NARCOTICS UPON THE CHARACTER OF THE USER. Dr. To gives us the answer. It is because drug addiction causes a relentless destruction of character and releases criminal tendencies." (Emphasis as in original).

14. Id. at 4 :

"Medical authorities agree that the treatment of addiction with the view toward effecting a cure, which makes no provision for confinement while the drug is being withdrawn, is a failure, except in a relatively small number of cases where the addict is possessed of a much greater degree of will power than the average addict."

15. See testimony of Commissioner Harry J. Anslinger, Fed. Bur. of Narcotics, in Hearings before Special Committec to Investigate Crime in Interstate Commerce, 82d Cong., 1st Sess. pt. 14, pp. 426-32 (1951). 
and anyone who raises a dissenting voice is most likely a bungling "dogooder"16 or one who wants to undermine the foundations of our society. ${ }^{17}$ The states have been pushed and swept along this same vindictive line of approach, ${ }^{18}$ with very few dissents. ${ }^{19}$ And the present campaign is as vigorous and formidable as ever. ${ }^{20}$ To this campaign, the judiciary made its own contribution in a series of decisions rendered in the 1920's and to which we now turn.

\section{The Narcotization of the High Court}

\section{Dr. Behrman and His Predecessors}

Before the Narcotics Division could really turn the nation into a happy hunting ground, stocked with addicts as fair game, it had to drive the medical profession out of the way. As has been noted. Section 2 of the Harrison .tet exempted the prescription of drugs "to a patient by a physician ... in the course of his professional practice only."':1 This was unrevealing draftsmanship, ${ }^{22}$ and many doctors felt that the agonies of unrelieved addiction were as much encompassed in their Hippocratic Oath as any other human suffering.

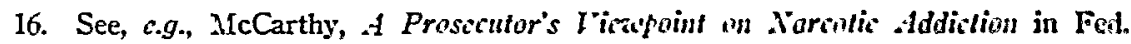
Prohib. Q., October, 1943 (reprinted and distributed by the Federal Rureau of Narcitiss in 1945).

17. In the Chicago Daily News. December 15, 1952, the last argument in cxircuis was set forth by local public oficials of that city: propunents of clinie truturent for narcotic addicts are obviously communists or communist-inspired, sceling to destruy the integrity of the American people.

18. Illinois Legislative Council, Disposithox of Narcotic Law Orfesidiss amil AdDICTs 12-19 (1951). A careful distinction must be made between inearceration for $s c_{\text {, }}$ and programs which place true emphasis on treatment and rehabilitation. The icdsral hospitals at Lexington, Ky., and Fort Worth, Texas, are admirable esamples ui the latter.

19. Governors Green and Stevenson both vetoed incarceration laws for the state of Illinois because no provisions for adequate treatment had been made. Vetu messages, July 24, 1947, and August 9, 1949, respectively. In the words of Governor Stevenson:

"It appears that the provision in this Bill authorizing imprisonment may have been intended only as a threat to compel the addict to undergo treatment, but whatever may have been the intention in this regard, the Bill does authorize imprisonment for a condition which it is admitted does not constitute a criminal act."

20. The Narcotics Bureau is pressing a bill, H.R. 3307, 83d Cong., 1st Sess. (1953), which would provide incarceration for all addicts in the District of Columbia. The worst feature of this bill-in the light of the full problem-is a "snealier" in the recitation of its purpose, which reads:

"The Congress intends that Federal criminal laws shall be enforced against

drug users as well as other persons. ..."

This may prove as effective, and as tricky, as the "rigged" indictment to which this article is principally addressed.

21. See note $\&$ sipra.

22. The legislative history of the provision sheds little light. The original draft required that the physician "shall personally attend upon such patient." H.R. Rer. No. 23, 
The Division's assault on this expression of the physician's conscience started in the courts. The Government aimed for a construction which would exclude from the Harrison Act exemption a doctor's dispensation of narcotics to ease an addict's craving. The attack had two objectives: to end all so-called ambulatory treatment ${ }^{23}$ (including the clinic system for controlled distribution of drugs to addicts ${ }^{24}$ ), and then, if possible, to drive the profession away from the addict altogether. It succeeded in both goals-for a brief period. But its short-lived success was enough, as we shall see. Government victories in the Supreme Court, culminating in United States v. Bchrman, pose two problems that are broader than the subject matter of this discussion. To what extent is it morally justified for an administrative agency to select the cases it feeds our appeals courts in order to gain some desired interpreta. tion or result? And how far ought the rule of stare decisis be extended into successive administrative actions and interpretations-particularly when the court decision underlying the original action has meanwhile been effectively overruled?

The Harrison Act came through its first constitutional test by a five-to-four margin. ${ }^{26}$ On the same day the Court decided Webb v. Unitcd Statcs, ${ }^{27}$ at physician case under the exemption in Section 2. The facts showed flagrant abuse; the doctor had sold prescriptions $-4,000$ of them in eleven monthsindiscriminately to anyone for 50 cents apiece. The issue was presented in a certified question:

"If a practicing and registered physician issues an order for morphine to an habitual user thereof, the order not being issued by him in the course of professional treatment in the attempted cure of the habit, but being issued for the purpose of providing the user with morphine sufficient to keep him comfortable by maintaining his customary use,

63d Cong., 1st Sess. 3 (1913). The Senate proposed changing this to: "shall have been specially employed to prescribe for the particular patient receiving such drug: And provided further, That such drug shall be dispensed in good faith and not for the purpose of avoiding the provisions of this act." SEN. Rep. No. 258, 63d Cong., 2d Sess. 4 (1914). The ensuing conference adopted the present language without edifying comment, mercly noting that the requirement of personal attendance had been dropped and that the dis pensing physician, etc., would be required to keep records. H.R. Rep. No. 1196, 63d Cong., 2d Sess. (1914).

23. There is a much-neglected distinction between prescription of narcotics 60 an addict for self-adninistration, and direct administration by the physician. The former is the subject of valid criticism, i.e., it does remove all restraints on consumption by the addict, and the drugs prescribed may be resold in the illicit traffic. There is merit in the suggestion, made from time to time, that all self-administration of narcotics should be made illegal. The "official line" has always ignored this distirction, equating prescription for self-administration with direct or supervised administration, and attacking both as "ambulatory treatment."

24. See notes 70, 72 infra; Comment, Narcotics Regulation, 62 YALE L.J. 751 (1952).

25. 258 U.S. 280 (1922). See pages 741-4 infra.

26. United States v. Doremus, 249 U.S. 86 (1919).

27. 249 U.S. 96 (1919). 
is such order a physician's prescription under exception (b) of $\S 2$ ?'2S

The Court replied:

"[T]o call such order for the use of morphine a physician's prescription would be so plain a perversion of meaning that no discussion of the subject is required." 20

Note how the question was loaded: "sufficient to keep him comfortable by" maintaining his customary use" is not a description of the facts of the case: it not only blankets the outright peddling involved in the case before the Court, but it also reaches toward the bona fide administration of drugs for the relief of a patient-addict.

The next case, Jin Fuey Moy v. United States, ${ }^{30}$ was likewise flagrant on its facts. The doctor had prescribed morphine to strangers iniliscriminately, in bulk, 8 to 10 grams at a time, for $\$ 1.00$ per gram. The Court, this time apparently choosing its own wording, said:

"Manifestly the phrases 'to a patient' and 'in the course of his professional practice only' are intended to confine the immunity of a registered physician, in dispensing the narcotic drugs mentioned in the act, strictly within the appropriate bounds of a physician's professional practice, and not to extend it to include a sale to a dealer or a distribution intended to cater to the appetite or satisfy the craving of one addicted to the use of the drug." 31

Again, the language goes beyond the facts of the case. It separates "professional practice" from any administration whatsoever "intended to cater to the appetite or satisfy the craving" of an addict.

Now the stage was set for Dr. Behrman. For purposes of finding the doctor a peddler for profit, the case presented an ideal set of facts. He was arrested in New York for giving one addict, at one time, for use as the addict saw fit, prescriptions for 150 grains of heroin, 360 grains of morphine, and 210 grains of cocaine. ${ }^{32}$ Again the question posed was whether this was "in the course of his professional practice only." The Government, however, drew up a trick indictment, alleging not that the prescriptions were incompatible with approved and proper therapeutic treatment, but instead alleging that, in effect, the drugs were given in a good faith attempt to cure the addict. ${ }^{33}$

23. Webb v. United States, 249 U.S. 96, 99 (1919).

29. Id. at $99-100$.

30. 254 U.S. 189 (1920).

31. Id. at 194 .

32. Enough, as the Supreme Court noted, for vier 3,000 standard injcetiuns. Initel States v. Behrman, 258 U.S. 280, 289 (1922).

33. After reciting the delivery to the addict, one Willie King, the indictment alleged "that on said date the said Willie Fing was a person addicted to the habitual use of morphine, heroin and coeaine and known by the duiendont to be so addicted; that on said date the said Willie King did nut require the administration of either morphine, heruin, or cueaine by reason of any 
Behrman demurred. The district judge delivered a brief tirade against "ambulatory treatment," but reluctantly sustained the demurrer, referring to a decision in another trick-indictment case, ${ }^{34}$ and closing with an inviting conclusion: "For the sake of uniformity in this district, however, I am disposed to follow precedent until the question is concluded by a decision of the Sitpreme Court."35

The Government appealed the case directly to the Supreme Court ${ }^{80}$ and promptly moved to advance it, stating in support of its motion:

"[The case involves] a matter of general public interest, vis... . . what is the meaning of the words in the course of his professional

disease or condition other than such addiction, and the defendant did not dispense said drugs or any of them to said Willie King for the purpose of treating any disease or condition other than such addiction; that none of the said drugs so dispensed by the defendant was administered or intended by the defendant to be administered to the said Willie King by the defendant or by any nurse or person, other than the said Willie King, acting under the direction of the defendant, nor were any of said drugs consumed or intended by the defendant to be consumed by the said Willie King in the presence of the defendant, but all of said drugs were put in the physical possession and control of the said Willie King with the intention on the part of the defendant that the said Willie King would use same by self-administration in divided doses over a period of several days, the amount of each of each of said drugs dispensed as aforesaid being more than sufficient or necessary to satisfy the craving of the said Willie King therefor if consumed by him all at one time; that said Willie King was not, at the time and place aforesaid, nor was he intended to be, during the period in which the drugs dispensed as aforesaid were to be used by him, under the observation and physical control of the defendant or of any nurse or other person acting under the direction of the defendant, nor was said Willic King in any way restrained or prevented from disposing of said drugs in any manner he might see fit; that said drugs dispensed by the defendant to the said Willie King as aforesaid were not mixed with any other substance, medicinal or otherwise, but were in the form in which said drugs are usually consumed by persons addicted to the habitual use thereof to satisfy their craving therefor and were adapted for such consumption; against the peace ... etc." Transcript of Record, pp. 2-3, United States v. Behrman, 258 U.S. 280 (1922).

For a rather complete paraphrase of the indictment, see United States v. Belirman, 258 U.S. 280, 286-7 (1922).

34. United States v. Balint, C. $28 / 136$, S.D.N.Y., June 28 , 1921, in Transcript of Record, pp. 4-5, United States v. Balint, 258 U.S. 250 (1922), in which the indictment alleged violation of $\S 2$ of the Harrison Act without including the word "willfully." Defendant's demurrer to the indictment was sustained, and the indictment dismissed. Ibid. The dismissal was ultimately reversed by the Supreme Court, United States v. Balint, supra, which ruled that it was not necessary that defendant have knowledge of the fact that the product sold was a drug whose sale was regulated by the Act.

35. United States v. Behrman, C. 28/425, S.D.N.Y., Sept. 21, 1921, in Transcript of Record, pp. 5-6, United States v. Behrman, 258 U.S. 280 (1922).

36. Under the Criminal Appeals Act, 34 Stat, 1246 (1907), now as amended, 18 U.S.C. \& 3731 (Supp. 1951). 
practice only' in that portion of the Act which exempts from its provisions the dispensing or distribution of the drugs to a patient by a physician 'in the course of his professional practice only.'

"The practical administration of the Harrison Narcotic . Act is dependent, to a very large extent, upon the decision which this court may render in [this case]."37

In the Behrman brief, Solicitor General Beck made no attempt to gloss over what was being sought, apparently relying-rightly, as the outcome provedon the flagrancy of the case and the prevailing temper of the times: 35

"The purpose of this indictment and of the present writ of error is to raise for the determination of this court the following questions, viz., whether the so-called 'ambulatory treatment' of drug addicts by a physician is or is not. as a mattcr of lazi', prohibited by section 2 of the Harrison Narcotic Act. . . . By the term 'ambulatory treatment' is meant the treatment by a physician of a drug addict, for the allegred cure of his drug addiction. by giving to him a prescription for the amount of the drug which the physician, in good faith, believes to be necessary in the condition of the drug addict at the time the prescription is given, for his use as one dose or over a period of time, and allowing the addict to take the prescription and to use it in any manner he may see fit, without any supervision or control of the doctor over him in any manner or form whatsoever. 39

“...

"The theory of the indictment is that this action upon the part of the defendant was, not a question for the jury, either on the defendant's intent, or as to what constituted the legitimate practice of his profession, but a violation of the Harrison Narcotic Act as a matter of laze. ...

"In order that the matter may be made perfectly clear, it should be again insisted that, according to the indictment, the so-called 'patient' in this case was suffering from no disease whatever except drug addiction. It must be admitted, for the purpose of the case at bar, that drug addiction is a disease, and that the defendant intended by his method of treatment to cure the same, and honestly believed that he could cure the disease by this method. Nevertheless, it is a well known fact, of which this court has taken notice, that drug addicts as a class are persons weakened materially in their sense of moral responsibility and in their power of will, and this court also linows, as a matter of common knowledge, that, in any community where drugs are prescribed, there will be a large number of physicians to whom any construction of section 2 of the Harrison Narcotic Act will be applicable. The question therefore, is whether every physician licensed and registered under the Harrison Narcotic Act, is at liberty, if he honestly believes such a course to be proper, to furnish to per-

37. Motion to Advance, p. 2, United States v. Balint, 358 U.S. 350 (1622), Linited States v. Behrman, 258 U.S. 280 (1922).

38. Brief for United States, pp. 7-8, 12-13, 13, United States v. Eehrman, 35: C.S. 280 (1922).

39. This description was far from precise. See note 23 sipro. 
sons of the character of drug addicts the means to obtain drugs without any supervision upon the part of the various doctors involved of the manner or time of taking the drugs or whether, indeed, the drugs are ever taken by the addict at all.

“...

"It is true that in the Doremus, Webb, and Jin Fuey Moy cases it was assumed that the physician ... . did not honestly intend to effect a cure of the drug addiction and did not honestly believe that his method would effect a cure, but was merely administering the drug to satisfy the cravings of the addict; and that this court is asked in the case at bar to go beyond these decisions, and to hold that, irrespective of the physician's intent or belief, the act is violated where the drugs are placed by him in the sole control and subject to the unrestricted disposal of the drug addict."

Justice Day and five of his associates sustained the Government's position, reversing the district court and thus putting the stamp of approval on the Behrman indictment. That the majority of the Court did not see clearly what they were doing - notwithstanding the Government's candid brief-is apparent from the fact that they relied heavily on the mere amount of the prescriptions, ${ }^{40}$ apparently without realizing that the doctrine they were setting would make volume-and good faith, as well-irrelevant. The other three Justices, Holmes, Brandeis, and McReynolds, were more clairvoyant. Justice Holmes wrote for them:

"It seems to me wrong to construe the statute as creating a crime in this way without a word of warning. Of course the facts alleged suggest an indictment in a different form, but the Government preferred to trust to a strained interpretation of the law rather than to a finding of a jury upon the facts. I think that the judgment should be affirmed." 41

\section{After Behrman}

If some members of the Court were not fully aware of what they were giving in the Behrman holding, the Narcotics Division nonetheless saw perfectly clearly what it had received. Manifestly, if a Behrman indictment was unassailable when it charged the dispensing of shocking amounts of drugs, it was no less unassailable when it charged a minute quantity only. The Division had what it wanted. Any doctor who prescribed any narcotic drug to any addict could be threatened with prosecution or packed off to prisonand good faith was no defense. Immediately there commenced a reign of terror.

The medical profession was shamelessly bullied and threatened, until it withdrew, totally and irrevocably, as the addict's last point of contact with society. ${ }^{42}$ The narcotics clinics, which had been established in a number of

40. United States v. Behrman, 258 U.S. 280, $288-9$ (1922).

41. Id. at 290 (dissent).

42. It is noteworthy, for its bearing on the addicts-are-criminals argument, inter alic, that addiction among doctors themselves has always been a problem, alluded to by the 
states to alleviate the situation, were closed-in some instances as a direct result of threats by Division agents. ${ }^{13}$ In 1924 a special committee of the American Medical Association docilely reported its "firm conviction" that ambulatory treatment of narcotics addicts "begets deception, extenrls the abuse of habit-forming narcotic drugs, and causes an increase in crime."14 . In earlier version of this report (prior to its adoption by the A.MI.A.) had been reprinted by the Division (a practice, as to "approved" materials, that continues to this day) and had been widely circulated as an officially endorsed pronouncement. ${ }^{45}$

Doctors went to prison. ${ }^{46}$ The hunt for addicts was pressed relentlessly. Prices rose, prisons filled, “dope rings" throve. The United States acquired the renown of being the world's best market for illicit narcotics-a reputation which stands unchallenged to this day.

When the Supreme Court was jolted into further action, it was too late for the Justices to alter the situation. They spoke firmly, but to no avail.

\section{Dr. Linder's Case: A Theoretical Reversal}

The jolt took the form of the next Behrman indictment case to reach the Supreme Court.48 The facts in this case were fully as outrageous as in Dr. Behrman's case, but invoked the opposite alignment of sympathy. Dr. Charles O. Linder was a long-established practitioner in Spokane, I'ashington, with a large practice. At four o'clock one Saturday, while he was examining a female patient, with other patients waiting for him, four Narcotics Division agents burst in upon him, and "boisterously and in an ungentlemanly and forcible manner, took charge" of his office. When he protested, the agents showed their Treasury Department badges and told him, "This is sufficient." After a rowdy search they took him off to jail. ${ }^{40}$

Dr. Linder was indicted in a word-for-word repetition of the Bchrman indictment, only this time the amount was three small tablets of cocaine and

narcotics authorities year after year in thir annual reports. Sce, c.4., C".S. Trus,

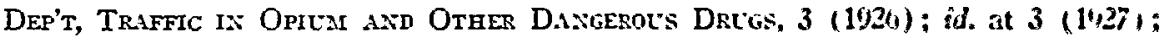
id. at 4 (1928).

43. See, New York Times, Iune 23, 1920, p. 8; Stevens, sufra note 7, at 43.

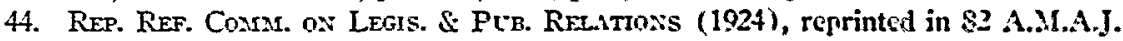
1967 (1924).

45. Stevens, supra note 7 , at 43.

46. See Simmons v. United States, $300 \mathrm{Fed} .321$ (6th Cir. 1924) ; Hobart v. Lnited States, 299 Fed. 784 (6th Cir. 1924) ; Manning v. United States, 287 Fed. $\$ 00$ ( 8 th Cir. 1923).

47. For many years the Division reported its "score" (in a column with otler statistics) by the number of years in sentences imposed: c.g., (1920) 10,342 violations, 5,120 convictions, 6,797 years, 11 months, 10 days; (1928) 8,653 violations, 4,738 convictions, 8,786 years, 4 months, 28 days; (1933) 3,468 violations, 1,694 convictions, 3,248 years, 10 months, 18 days. See U.S. Tress. Dep't, The Triffic in Onuns and Uther DANGerous Drugs (1926) and subsequent yearly reports.

48. Linder v. United States, 268 U.S. 5 (1924).

49. Motion to Quash Search Warrant, Transcript of Record, Linder v. Unitcd States, 268 U.S. 5 (1924). 
one of morphine. These had been given to an "addict-stool pigeon," who was working for the agents. She claimed she had told him she was an addict; in his version she had represented that she had a painful stomach ailment and that the doctor who regularly treated her was out of the city..$^{50}$

Linder was convicted, ${ }^{51}$ the Ninth Circuit affirmed, ${ }^{52}$ and he petitioned for certiorari, arguing:

"The [Harrison] act ... was not intended to trench on the police power of the states, and ought not to be given an interpretation which would bring within its purview an act the cognizance of which properly belongs to the states. .. [ [T] he lower courts almost uniformly try these narcotic cases on the theory that the purpose of the statute was to punish physicians and others dispensing morphine or other narcotics to satisfy the cravings of drug addicts, even where all the revenue features of the act have been complied with, as registration, payment of the tax, and the making and keeping of the records required by the act. We submit that the United States has nothing to do with such acts. Whether the health and morals of their people require that such practices be repressed by penal sanction is for the states alone to determine." “...

"Now what is the nature of the act charged in the indictment, giving the indictment the widest scope claimed for it? Simply that the defendant, being a registered physician, dispensed a small quantity of narcotic drugs to gratify the appetite of an addict." 53

When the petition was granted, Solicitor General Beck disposed of the merits, in the Government's brief, in a pithy five-page statement that attempted merely to pin the Court to its earlier declared position:

"Petitioner contends in substance that if the indictment and the statute upon which it is founded, be construed as charging the administration of drugs merely to gratify the appetite of an addict, such an offense is beyond the power of Congress to create. . . .

"This is precisely what the indictment and the statute cover, and what the court intended to uphold in U.S. v. Behrman, 258 U.S. $280,287,288 . \ldots$

"The indictment in the case at bar is framed in the same language as the indictment in the above-mentioned Behrman case, except for the amount of the drug alleged to have been sold or clistributed otherwise than in the course of professional practice. No distinction, however, can be made between the two cases on the ground merely of the difference between the amounts of drugs which are charged in the two indictments. In the Behrman case, supra, this court had before it only the strict allegations of the indictment, and for that

50. Transcript of Trial, Linder v. United States, 268 U.S. 5 (1924).

51. His sentence: $\$ 1000$ and two months in jail. Transcript of Record, pp. 25-6, Linder v. United States, 268 U.S. 5 (1924).

52. Linder v. United States, 290 Fed. 173 (9th Cir. 1923).

53. Brief in Aid of Petition for Writ of Certiorari, pp. 9-11, Linder v. United Statc:, 268 U.S. 5 (1924). 
purpose the amount of the drug becomes immaterial in determining whether the indictment actually and sufficiently charges it to have been unlawfully sold or distributed.

“...

"Petitioner also contends that the indictment is capable of the construction, in substance, of charging that the drug was given in the professional treatment of the addict. The Belmoman case, supra, must be held to dispose adversely of such claim, for if the indictment there, of which the indictment at bar is a duplicate in allegation, had been capable of such construction, this court would have said sa."

The Court's opinion, handed down in 1925, was written by Justice McReynolds, and was unanimous. Dr. Linder's conviction was reversed, and the opinion is as emphatic in tone as circumstances could permit:

"The enactment under consideration levies a tax, upheld by this court. upon every person who imports, manufactures, produces, compounds, sells, deals in. dispenses or gives away opium or coca leaves or derivatives therefrom, and may regulate medical practice in the States only so far as reasonably appropriate for or merely incidental to its enforcement. It says nothing of 'addicts' and does not undertake to prescribe methods for their medical trcatment. They are diseased and proper subjects for such treatmont, and we cannot possibly conclude that a physician acted improperly or unwisely or for other than medical purpose solely because he has dispensed to one of them. in the ordinary course and in good faith, four small tablets of morphine or cocaine for relicf of conditions incidcnt to addiction." "ت

Of the $W e b b$ case, ${ }^{50}$ the Court said:

"The answers thus given must not be construed as forbidding every prescription for drugs, irrespective of quantity, when designed temporarily to alleviate an addict's pains, although it may have been issued in good faith and without design to defeat the revenues."

Of the Jin Fuey Moy case::s

"The quoted language must be confined to circumstances like those presented by the cause."53

And of the Behrinan case ${ }^{60}$ itself:

"This opinion related to definitely alleged facts and must be so understood. ... The opinion cannot be accepted as authority for holding that a physician who acts bona fide and according to fair medical standards, may never give an addict moderate amounts of drugs for self-administration in order to relieve conditions incident to addiction.

54. Brief of United States, pp. 3-5, Linder v. United States, 268 U.S. 5 (1924).

55. Linder v. United States, 268 U.S. 5, 18 (1925) (emphasis added).

56. Webb v. United States, 249 U.S. 95 (1919).

57. Linder v. United States, 268 U.S. 5, 20 (1925).

58. Jin Fuey Moy v. United States, 254 U.S. 189 (1920).

59. Linder v. United States, 268 U.S. 5, 20 (1925).

60. United States v. Behrman, 258 U.S. 280 (1921). 
Enforcement of the ta.x demands no such drastic rule, and if the Act had such scope it would certainly encounter grave constitutional difficulties."61

The lower federal courts have since been fairly true to this corrected interpretation of the Harrison Act, when they have had opportunities to express themselves. ${ }^{62}$ But there have been few significant cases. The doctors are still in retreat. And the Federal Narcotics Bureau has been undeterred in its own lusty applications of the Act. Its regulations uncler Section 2 od still provide (paraphrasing the loaded question in the discredited $W c b b$ case $\left.{ }^{64}\right)$ :

"An order purporting to be a prescription issued to an addict or habitual user of narcotics, not in the course of professional treatment but for the purpose of providing the user with narcotics sufficient to keep him comfortable by maintaining his customary use, is not a prescription within the meaning or intent of the Act; and the person filling such an order, as "well as the person issuing it, may be charged with violation of the law."65

\section{ConcLusion}

It wasn't many decades ago that sufferers from tuberculosis, sub nomine "consumption," were regarded as unclean, and shunned by society. We have stopped treating our insane population as felons, raised the ancient stigma from leprosy and epilepsy, and transformed our penal philosophy from one of vengeance to one of rehabilitation. We have shown growing interest in largescale attempts to salvage the victims of alcoholism; we caught up with most of our error vis-a-vis the liquor drinker fifteen years ago. ${ }^{66}$ And we have made venereal afflictions the subject of wholesome programs and campaigns. But we have not shown comparable understanding of the addict's problems.

The true addict, by universally accepted definitions, is totally enslaved to his habit. He will do anything to fend off the illness, marked by physical and emotional agony, that results from abstinence. So long as society will not traffic with him on any terms, he must remain the abject servitor of his vicious nemesis, the peddler. The addict will commit crimes-mostly petty offenses like shoplifting ${ }^{67}$ and prostitution-to get the price the peddler asks. He werill

61. Linder v. United States, 268 U.S. 5, 22 (1925) (emphasis added).

62. See United States v. Brandenberg, 155 F.2d 110 (3d Cir. 1946).

63. See note 8 supra.

64. Webb v. United States, 249 U.S. 96 (1919).

65. U.S. Treas. Dep't, Narcotics Bureau Reg. No. 5, art. 167 (1949), 26 Code Fin. REGS. \& 151.167 (1949).

66. This analogy goes further. It was in the heyday of the bootlegger that organized crime, as we know it today, got its start. Revenues from the illicit narcotic traffic arc, next to gambling, the largest current source of underworld wealth. Quite apart from humanitarian considerations, we should end this billion-dollar-a-year subsidy to the nation's real criminals.

67. See Comment, Shoplifting and the Law of Arrest: the Merchant's Dilcmma, 62 YALE L.J. 788, 791 n.36 (1953). 
peddle dope and make new addicts if those are his master's terms. Drugs are a commodity of trifling intrinsic value. All the billions our society has spent enforcing criminal measures against the addict have had the sole practical result of protecting the peddler's market, artificially inflating his prices, and keeping his profits fantastically high. ${ }^{68}$ No other nation hounds its addicts as we do, and no other nation faces anything remotely resembling our problem.

Where does the solution lie? Out of reach, for the moment, because we shall not undo forty years of carefully wrought error overnight. Out of sight. also, at least in precise detail, because we have little reliable data to guide us. But-at least until they are fully explored-the road would seem to lead towards the following areas: (1) relief from persecution for the addict; (2) therapy programs through institutions, ${ }^{60}$ clinics, ${ }^{70}$ and after-cure followups ;1 (3) provisions for incurables, through clinics or the individual practitioner or both ; ${ }^{72}$ (4) a forthright out-of-the-dark educational program on narcotics; and (5) a vigorous assault, with all the enforcement resources we can muster, on whatever is left of the peddlers' empire after we have freed the addict from his present bondage to it.

Sooner or later some responsible appraiser, probably Congress, will have to take a clear look at our narcotics problem and the plight of the addict. It is to be hoped that re-telling this tale, of Dr. Behrman, who was rightly punished for the wrong reasons, and Dr. Linder, who was vindicated in vain, may hasten the advent of that happy day.

68. At frequent intervals the federal narcotics authorities publish tables of the going

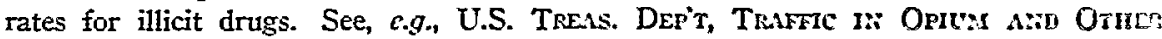
Dangerous Drtgs 26 (1930). In this issue the Narcutics Division notes a "marlsod general increase in the prices of narcotic drugs. . . . This is a fair indication of tha relative scarcity of narcotic drugs in the illicit market, due to increased cficiency of narcotic-law enforcement."

69. Such as the federal hospitals administered by the L.S. Public Health Servic: 58 Sтat. 698 (1944), 42 U.S.C. $\$ 257$ (1946), the North Brother Island Hospital experiment in New York, and the proposed Seabrook Farm Unit in New Jersey.

70. A bill to create a Federal Bureau of Clinics, to develop this approash to the problem, is now pending in Congress: H.R. 2449, 83d Cong., 1st Sees. (1053). The bill also includes alcoholics, as beneficiaries of the same program. For discussion of clinic system merits, see Comment, Narcotics Regulation, 62 XALE L.J. 751. 784-7 (1953).

71. This would perhaps be another function of narcutic clinies; it is contemplated, in connection with H.R. 2449, stpra note 70, that ather federal agencies, such as the U. S. Employment Service, would be called upon to cooperate in ylacing and rehabilitating addicts.

72. See Stevens, Make Dope Legal, Harpers Mlagazine, November, 1952, p. \&0. 


\section{THE YALE LAW JOURNAL}

\section{EDITORIAL BOARD \\ ERNest RUBENSTEN \\ Editor-in-Chief \\ ARNOLd M. LERMAN \\ WiLliard R. MURphy \\ Executive Editors}

Williak M. BRAdNer

ANDREW C. HAARTZELI, JR.

STUART C. LAW

STUART ROBINOWITZ

H. RICEARD UVIILER

Note and Comment Editors

\author{
JoHN G. SimoN \\ Article and \\ Book Review Editor
}

JoHN W. Frommen, Jr. Case Editor

Charles R. Bergofyen

MAURice N. Nessen Managing Editors

Immanuer. Komn RICHAID I. M. KELTON Leonard M. Pousar JEROME S. WAGSTIL
George Berlstein

Theron I. Caudle, Jr. Peter S. Crajg

William A. Delano

Kuaus Dohnanyi
JOHN D. FASSETT

Charzes E. Fraser

ARTHUR B. FronMmer

Alice B. Gilbert

ANDREW D. HeINEMAAN, Bus. Mgr.

Editor in Military Service

BarRy H. Garfinkel, Managing Editor

Marie McMahon

Biwsiness Secretary

\section{CONTRIBUTORS TO THIS ISSUE}

Fleming Janes, Jr. B.A. 1925, LL.B. 1928, Yale University. Co-author, SHuldsan \& Janres, Cases on Torts (1942). Lafayette S. Foster Professor of Law, Yale Law School.

Rufus G. Kung. B.A. 1938, Princeton University; LL.B. 1943, Yale University. Consultant, American Bar Ass'n Commission on Organized Crime. Formerly Ass't Counsel, Senate Crime Committee. Currently Special Counsel, Subcommittee to Investigate the Justice Department, House Committee on the Judiciary; Investigations Subcom* mittee, Senate Committee on Interstate Commerce. Member, New York and District of Columbia Bars. 